Vol. 1, Issue 1, pp. 001-009

\title{
Performance improvement of manufacturing industry by reducing the Defectives using Six Sigma Methodologies
}

\author{
Chethan Kumar C $\mathbf{S}^{\mathbf{1}}$ \\ ${ }^{1}$ Assistant Professor, I.E.M Dept, M.S.R.I.T, Bangalore-560054
}

Dr. N V R Naidu ${ }^{2}$

${ }^{2}$ HOD, I.E.M Dept, M.S.R.I.T, Bangalore-560054

\author{
Dr. K Ravindranath ${ }^{3}$ \\ ${ }^{3}$ Principal, SVCE, Tirupati
}

\begin{abstract}
:
Studies have investigated how quality management can be employed in lean manufacturing to improve the performance of various issues in the whole business processes of various industries. This research work develops an application guideline for the assessment, improvement, and control of wastes in garment industry using six-sigma improvement methodology. Improvements in the quality of processes lead to cost reductions as well as service enhancements. An attempt is made to introduce and implement DMAIC methodology in Sun garment industry located in Coimbatore.
\end{abstract}

\section{Define Phase}

- Research Case: As quality plays a pivotal role in all aspects of life, reducing the number of defectives in garment industry is an important function. Garment industries in India are facing stiff competition from Sri Lanka, Bangladesh and China. At this critical juncture, it is paramount for the manufacturers to reduce defects in their products and become competitive.

- Problem Statement: The garment industries are suffering from high rate of rejections of their products.

- Goal Statement :

$\circ$ To reduce the defect $\%$ to minimum level and thereby improve quality, reduce wastes and increase productivity

- Team : 3 members

- CTQ (Critical to Quality Characteristic) : Defective \% of shirts

- SIPOC:

The SIPOC Table.1.1 is developed to identify the requirements of the customers and other processes. 


\section{Chethan Kumar C S, Dr. N V R Naidu, Dr. K Ravindranath/ IOSR Journal of Engineering (IOSRJEN)

Vol. 1, Issue 1, pp. 001-009

Table.1.1: SIPOC flow at Sun Garments

\begin{tabular}{|c|c|c|c|c|}
\hline Supplier & Inputs & Process & Output & Customer \\
\hline $\begin{array}{l}\text { Madura } \\
\text { Coats }\end{array}$ & $\begin{array}{ll}\text { - } & \begin{array}{l}\text { Unstitched } \\
\text { cloth. }\end{array} \\
\text { - } & \text { Machinery } \\
\text { - } & \text { Threads } \\
\text { - } & \text { Needles }\end{array}$ & $\begin{array}{ll}\text { - } & \text { Cutting } \\
\text { - } & \text { Fabric } \\
\text { components } \\
\text { - } & \text { Stitching } \\
\text { - } & \text { Pressing } \\
\text { - } & \text { Packaging }\end{array}$ & Stitched shirt & Indigo \\
\hline
\end{tabular}

\section{Measure Phase:}

In this phase, after discussions with the managers and supervisors data is collected with the help of team members.

1. Data Collection Period

Table.1.2: Data collection period

\begin{tabular}{|l|l|l|}
\hline Period & Variables (CTQ) & Responsibility \\
\hline $\begin{array}{l}\text { May-December } \\
2009\end{array}$ & $\begin{array}{l}\text { Total Checked } \\
\text { Defectives }\end{array}$ & Team \\
\hline
\end{tabular}

2. The company manufactures variety of garment products like shirts, pants and Jackets. One product, i.e., Executive Shirt is inspected for defects since this was the critical product for the company as it had lot of demand and the profit margin for this particular product is high. Table.1.3 indicates the total number of shirts checked and the number of defectives.

Table.1.3: Inspection of Shirts.

\begin{tabular}{|l|l|l|}
\hline $\begin{array}{l}\text { Batch } \\
\text { Number }\end{array}$ & $\begin{array}{l}\text { Checked } \\
\text { pieces }\end{array}$ & Defectives \\
\hline 1 & 237 & 15 \\
\hline 2 & 525 & 23 \\
\hline 3 & 626 & 33 \\
\hline 4 & 757 & 26 \\
\hline 5 & 754 & 35 \\
\hline 6 & 807 & 38 \\
\hline 7 & 1064 & 33 \\
\hline 8 & 719 & 26 \\
\hline 9 & 363 & 20 \\
\hline 10 & 310 & 17 \\
\hline
\end{tabular}




\section{Chethan Kumar C S, Dr. N V R Naidu, Dr. K Ravindranath/ IOSR Journal of Engineering}

(IOSRJEN)

Vol. 1, Issue 1, pp. 001-009

\begin{tabular}{|l|l|l|}
11 & 315 & 16 \\
\hline 12 & 242 & 15 \\
\hline & Total $=6719$ & Total $=297$ \\
\hline
\end{tabular}

3. Capability Study:

The analysis is carried out using MiniTab Software. The results are evident from the Figure.1.1

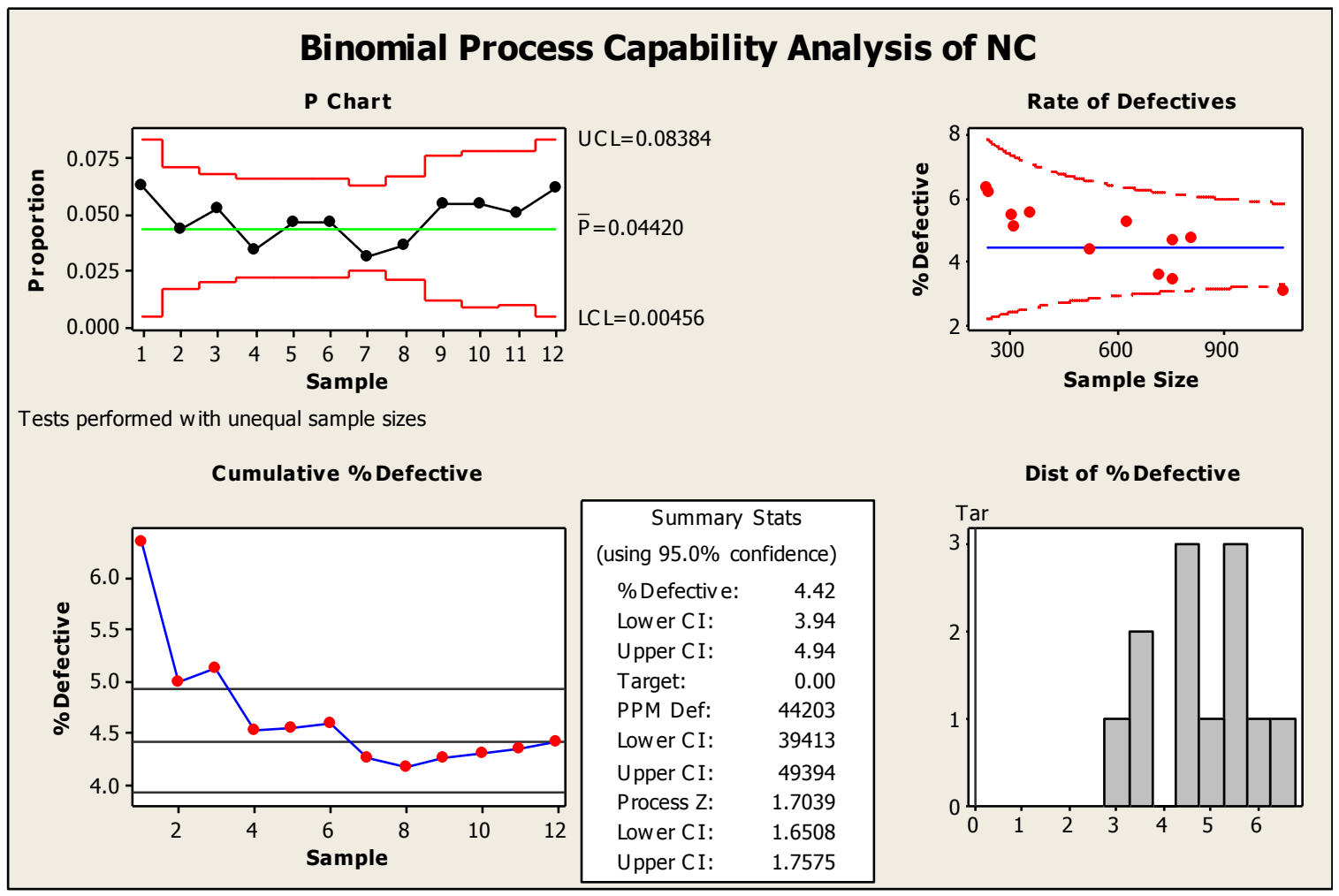

Figure 1.1: Capability study

\section{Analysis:}

The outcome is given in the Table.1.4. Showing \% defectives as 4.42 .

Table 1.4: calculation of dpmo

\begin{tabular}{|l|l|r|}
\hline Sl.No & Total Checked & 6719 \\
\hline 1 & $\begin{array}{l}\text { No. of } \\
\text { Defectives }\end{array}$ & 297 \\
\hline 2 & $\%$ Defectives & $4.42 \%$ \\
\hline 3 & dpmo & 44203.0064 \\
\hline 4 & Sigma & 3.20 \\
\hline 5 & dpo & 0.044203 \\
\hline
\end{tabular}




\section{Chethan Kumar C S, Dr. N V R Naidu, Dr. K Ravindranath/ IOSR Journal of Engineering}

(IOSRJEN)

Vol. 1, Issue 1, pp. 001-009

\section{Analyze Phase}

The past data was collected on the causes or type of defects and is given in Table 1.5

Table 1.5: Types of defects

\begin{tabular}{|c|l|c|r|}
\hline SI.No & DEFECTS & Occurrence & \% Occurrence \\
\hline 1 & UNEVEN & 13 & $4.32 \%$ \\
\hline 2 & RUNDOWN & 64 & $21.26 \%$ \\
\hline 3 & BROKEN & 139 & $46.18 \%$ \\
\hline 4 & CUFF UP\& DOWN & 16 & $5.32 \%$ \\
\hline 5 & SIDE SEAM UNEVEN & 5 & $1.66 \%$ \\
\hline 6 & FRNT PLKT UP\& DOWN & 6 & $1.99 \%$ \\
\hline 7 & WCL BTN MISS & 13 & $4.32 \%$ \\
\hline 8 & OPENSEAM & 11 & $3.65 \%$ \\
\hline 9 & BTN 2 HOLE & 7 & $2.33 \%$ \\
\hline 10 & RAW EDGE & 12 & $3.99 \%$ \\
\hline 11 & OTHERS & 15 & $5.0 \%$ \\
\hline & Total & 301 & \\
\hline
\end{tabular}

The major causes or types of defects were identified through Pareto Chart

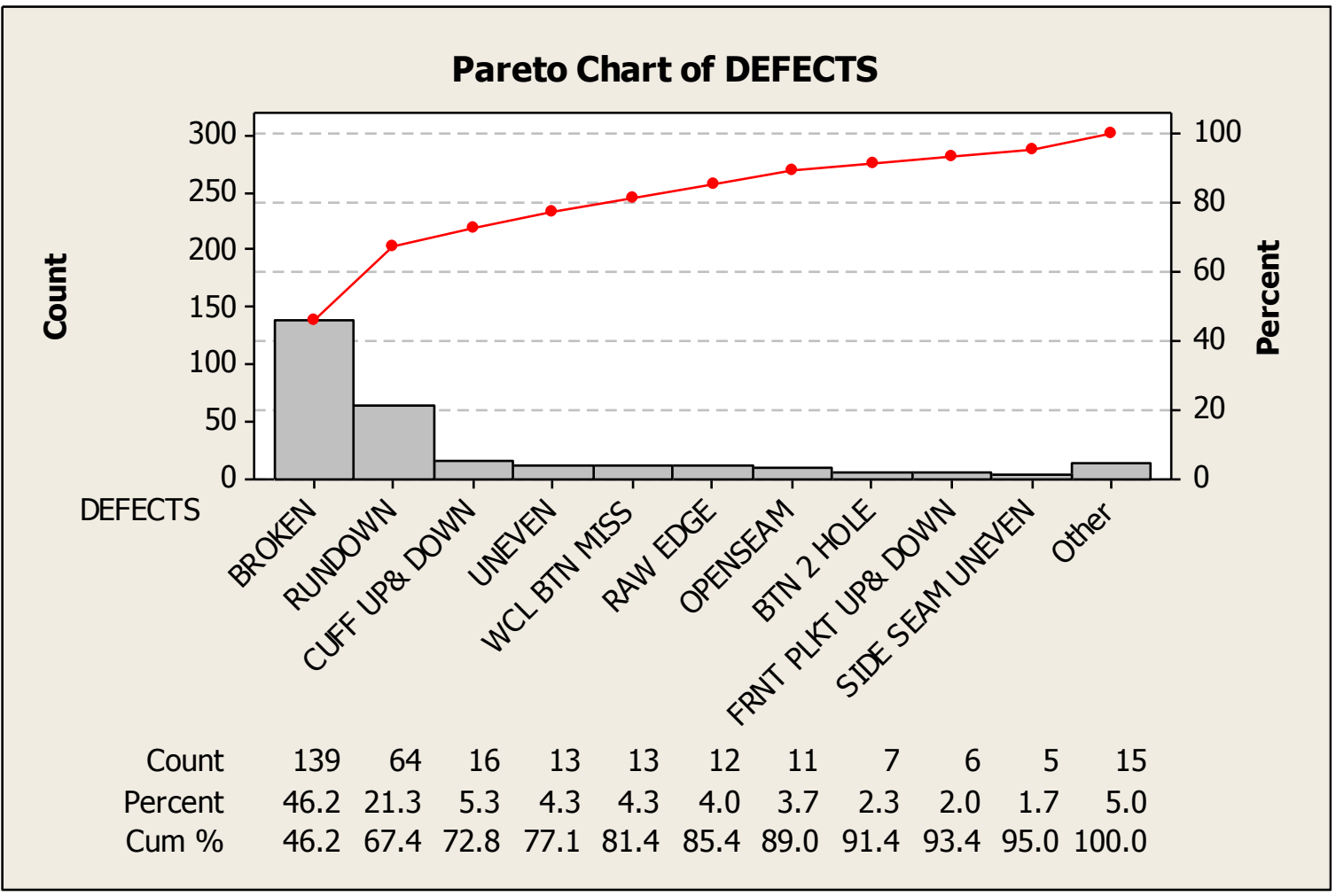




\section{Chethan Kumar C S, Dr. N V R Naidu, Dr. K Ravindranath/ IOSR Journal of Engineering (IOSRJEN)

\author{
www.iosrjen.org
}

Vol. 1, Issue 1, pp. 001-009

Figure 1.2 Pareto chart for types of defect

The major defects from Pareto Chart is considered for analysis and the defects are listed in Table: 1.6.

Table.1.6: Major defects identified from Pareto chart

\begin{tabular}{|c|l|}
\hline Sl.No & Defect Types \\
\hline 1 & BROKEN \\
\hline 2 & RUNDOWN \\
\hline 3 & CUFF UP\& DOWN \\
\hline 4 & UNEVEN \\
\hline 5 & WCL BTN MISS \\
\hline
\end{tabular}

Through brainstorming with the shop supervisors, all potential causes were identified. The identified causes are given in Figure 1.3 Cause \& Effect diagram. Only the major types of defects are considered for the cause and effect diagram

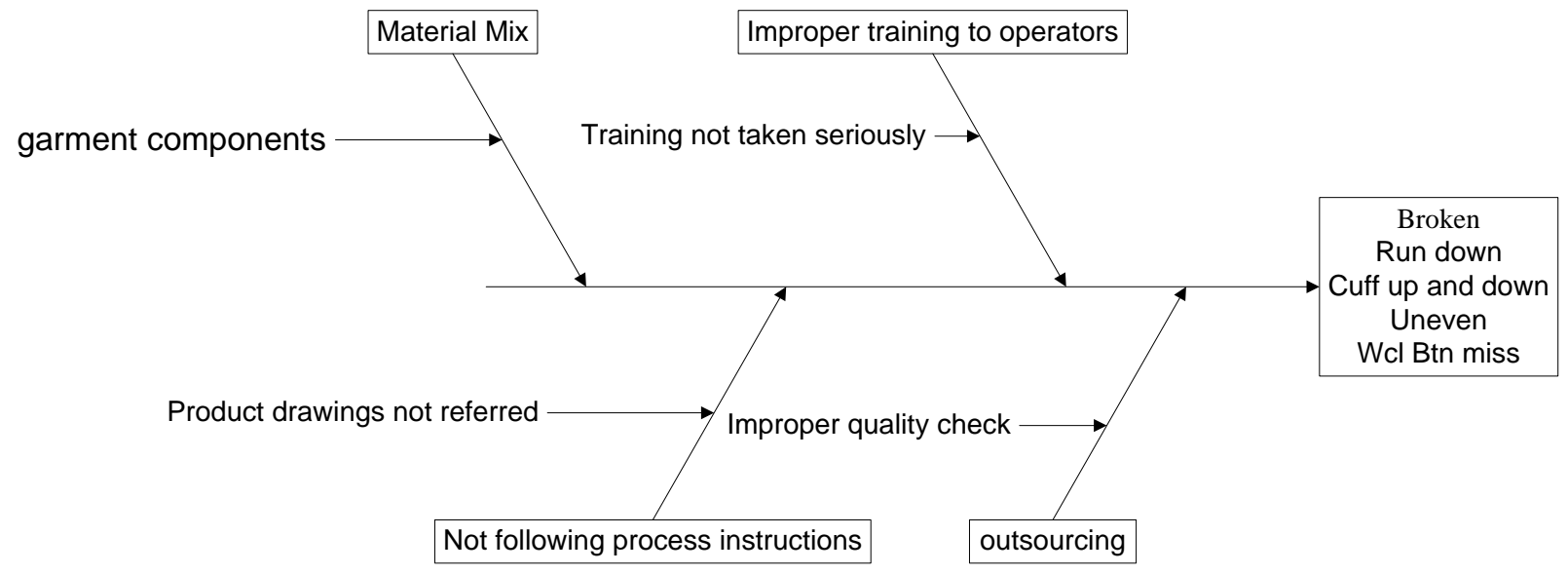

Figure.1.3: Cause and Effect diagram 


\section{Chethan Kumar C S, Dr. N V R Naidu, Dr. K Ravindranath/ IOSR Journal of Engineering (IOSRJEN)

Vol. 1, Issue 1, pp. 001-009

\section{Improve Phase}

Through discussions with the managers and supervisors the following remedial actions were implemented for the each cause which is indicated in the Table.1.7

\section{Table.1.7: Defects and remedial actions}

\begin{tabular}{|l|l|}
\hline DEFECTS & Action \\
\hline BROKEN & $\begin{array}{l}\text { The broken threads are due to the fabric and the initial swatch test is tightened so } \\
\text { that wrong fabric does not roll out. }\end{array}$ \\
\hline RUNDOWN & $\begin{array}{l}\text { The stitches are extended than required and the operators are trained to control the } \\
\text { speed of the machine }\end{array}$ \\
\hline CUFF UP\& DOWN & $\begin{array}{l}\text { The operators are compelled to refer to the drawings whenever they are stitching } \\
\text { Cuffs. }\end{array}$ \\
\hline UNEVEN & $\begin{array}{l}\text { The operators are trained to check for unevenness by using a sample fabric } \\
\text { pattern }\end{array}$ \\
\hline BTN MISS & $\begin{array}{l}\text { Operators are trained to check for the total number of buttons exhausted before } \\
\text { passing the product }\end{array}$ \\
\hline
\end{tabular}

\section{Implementation}

Based on the Cause and Effect diagram, the operators are trained in all aspects of their job and after the remedial actions are taken, the products are checked for defects. The details are indicated in Table.1.8

Table.1.8: Number of defectives for each batch

\begin{tabular}{|c|c|c|c|}
\hline Batch Number & $\begin{array}{l}\text { Checked } \\
\text { Pieces }\end{array}$ & Defectives & \% Defectives \\
\hline 1 & 243 & 4 & $1.65 \%$ \\
\hline 2 & 489 & 10 & $2.04 \%$ \\
\hline 3 & 655 & 11 & $1.68 \%$ \\
\hline 4 & 723 & 15 & $2.07 \%$ \\
\hline 5 & 769 & 17 & $2.21 \%$ \\
\hline 6 & 807 & 18 & $2.23 \%$ \\
\hline 7 & 932 & 15 & $1.61 \%$ \\
\hline
\end{tabular}

After remedial actions are taken to reduce the defects, the results are encouraging as shown in the Table.1.9 


\section{Chethan Kumar C S, Dr. N V R Naidu, Dr. K Ravindranath/ IOSR Journal of Engineering}

(IOSRJEN)

Vol. 1, Issue 1, pp. 001-009

Table: 1.9: Types of defects and \% Occurrence

\begin{tabular}{|l|r|r|}
\hline DEFECTS & Occurrence & \% Occurrence \\
\hline UNEVEN & 3 & $2.50 \%$ \\
\hline RUNDOWN & 15 & $12.50 \%$ \\
\hline BROKEN & 42 & $35.00 \%$ \\
\hline CUFF UP\& DOWN & 7 & $5.83 \%$ \\
\hline WCL BTN MISS & 5 & $4.17 \%$ \\
\hline Total & $\mathbf{7 2}$ & \\
\hline
\end{tabular}

Capability Study: Based on the Data recorded the capability study is conducted and is as shown in the Figure. 1.4

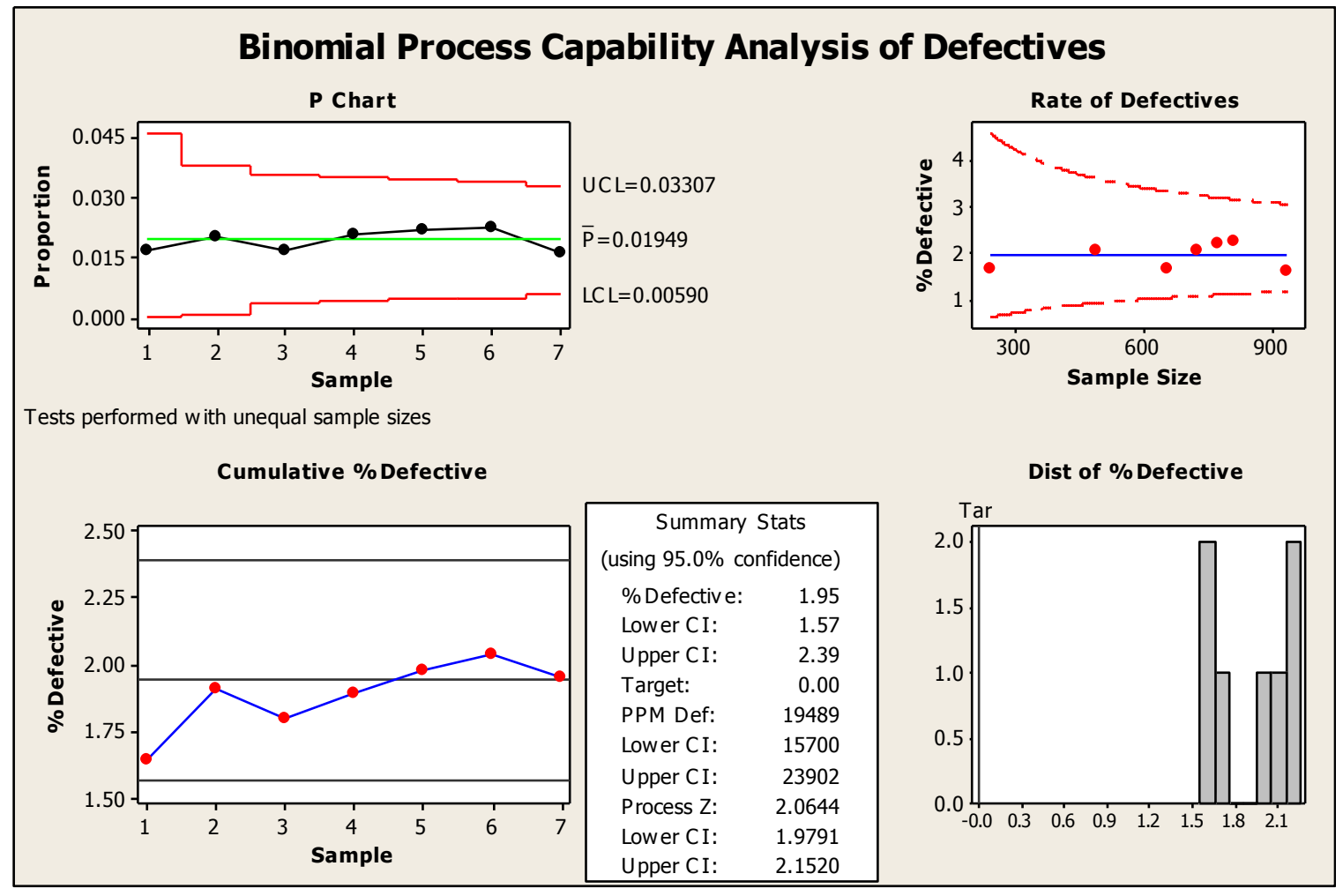

Figure.1.4: Capability Study after implementation

The results are indicating that the \% defectives has been reduced to $1.95 \%$ as indicated in Table 1.10 


\section{Chethan Kumar C S, Dr. N V R Naidu, Dr. K Ravindranath/ IOSR Journal of Engineering (IOSRJEN)

\author{
www.iosrjen.org
}

Vol. 1, Issue 1, pp. 001-009

Table.1.10: calculation of dpmo

\begin{tabular}{|l|r|}
\hline Total Checked & 4618 \\
\hline No. of Defectives & 90 \\
\hline$\%$ Defectives & $1.95 \%$ \\
\hline dpmo & 19488.96 \\
\hline Sigma & 3.56 \\
\hline
\end{tabular}

\section{Control Phase:}

The positive results are discussed with the managers of the garment industry. The major defects are identified and reduced. The real challenge is to sustain the improvements made in improving the process.

Control Plan: The following are the mandatory actions that has to be taken by the management to sustain the results after lean sixsigma implementation.

- The operators of garment industry must be given training on a continuous basis on the issue of quality.

- The drawings of the product must be made available at all the machines. The final garment pattern should be referred by all the operators.

- The management should give incentives for high quality performance.

- The focus should be on preventing defects rather than correcting defects.

- Tight quality controls should be enforced on those products coming from subcontractors.

- Training the subcontractors on the importance of quality on continuous basis.

\section{Conclusion:}

The garment industry in focus was exporting the final product to European countries. It was operating at a percentage defective of 4.42. After implementing the DMAIC methodology the percentage defective is reduced to 1.95. The same approach can be utilized to other products of the company which will reduce lots of defects. If the quantum of defectives are reduced and converted into cash flows, the company will benefit through increased revenues.

Many medium scale garment industries in India are not aware of the lean sixsigma concepts and this implementation will trigger a positive wave across the garment industries and become more competitive. 


\section{Chethan Kumar C S, Dr. N V R Naidu, Dr. K Ravindranath/ IOSR Journal of Engineering (IOSRJEN) \\ www.iosrjen.org}

Vol. 1, Issue 1, pp. 001-009

\section{BIBLIOGRAPHY}

[1] Bhavani, T.A. Suresh D. Tendulkar (2001), 'Determinants of firm-level export performance: A case study of Indian textile garments and apparel industry”, Journal of International Trade and Economic Development, 10:1, 65-92.

[2] Bruce, M., L. Daly and N. Towers, (2004), "Lean or agile: A solution for supply chain management in the textiles and clothing industry" International Journal of Operations and Production Management, vol. 24, no.2, pp 151-170.

[3] Chandra, P.,(2004) "Competitiveness of Indian Textiles \& Garment Industry: Some Perspectives," A presentation at Indian Institute of Management, Ahmedabad, December.

[4] Chandra, P., (1998),“Technology, Practices, and Competitiveness: The Primary Textiles Industry in Canada, China, and India”, Himalaya Publishing House, Mumbai,.

[5] Chandra,P.,(2005) “The textile and Apparel Industry in India”, Oxford University Press.

[6] Federation of Indian Chambers of Commerce and Industry, (2005), "Trends Analysis of India \& China's Textiles and Apparel Exports to USA - Post MFA", FICCI, New Delhi, July.

[7] Foster Jr., T., Howard, L., and Shannon, P., (2002), "The Role of Quality Tools In Improving Satisfaction with Government”, The Quality Management Journal, vol. 9, pp.20-31.

[8] George, M., (2002) “Lean Six Sigma, Combining Six Sigma Quality with Lean speed”, McGraw-Hill.

[9] Kapuge, A.M. and M. Smith, (2007), "Management practices and performance reporting in the Sri Lankan apparel sector", Management Audit Journal, vol. 22, no 3, pp 303- 318.

[10] Karim, S. (2009), "The Impact of Just-in-Time Production Practices on Organizational Performance in the Garments and Textiles Industries in Bangladesh”, Doctoral Thesis, Dhaka University.

[11] Keller, P., (2001), “Recent Trends in Six Sigma”, ASQ's 55th Annual Quality Congress Proceedings, pp 98-102.

[12] Mercado, G. (2008). “ Ask the Lean Manufacturing Experts Applying Lean in the Garment Industry”, Thomas Publishing Company

[13] Hoffman, J. and Mehra, S.,(1999), "Management Leadership and Productivity Improvement Programs", International Journal of Applied Quality Management, vol 2, no. 2, pp. 221-232. 